\title{
Photoredox Catalytic Trifluoromethylation and Perfluoroalkylation of (Hetero)arenes Using Trifluoroacetic and Related Carboxylic Acids
}

\author{
Dehang Yin, ${ }^{\ddagger}$ Dengquan Su, ${ }^{\star}$ and Jian Jin* \\ CAS Key Laboratory of Synthetic Chemistry of Natural Substances, Center for Excellence in Molecular Synthesis, Shanghai \\ Institute of Organic Chemistry, University of Chinese Academy of Sciences, Chinese Academy of Sciences, 345 Lingling \\ Road, Shanghai 200032, China
}

\begin{abstract}
A mild and practical method has been achieved that allows for the direct C-H trifluoromethylation, perfuoroalkylation and chlorodifluoromethylation of (hetero)arenes using inexpensive and abundant trifluoroacetic acid and the corresponding carboxylic acids. A diverse array of arenes and heteroarenes were successfully transformed into valuable fluoroalkylated compounds. The combination of photoredox catalysis and a diaryl sulfoxide provides a platform for the facile generation of fluoroalkyl radicals from the corresponding fluoroalkyl carboxylic acids under mild conditions.
\end{abstract}

Fluorine is the most electronegative element, which results in two facts just like two sides of the same coin. In general, fluorinated drugs have better membrane permeability and increased bioavailability compared with their non-fluorinated analogues because of the changes in the physical and chemical properties. ${ }^{1}$ On the other hand, the uniqueness of fluorine renders the installation of itself a challenging task. ${ }^{2}$ Trifluoromethyl group is one of the privileged moieties in modern drug discovery. Among the top 200 small molecule pharmaceuticals by retail sales in 2018 , there were 15 drugs containing at least one trifluoromethyl group, mostly (12 out of 15) on their aryl or heteroaryl scaffolds. Therefore, simple methodologies for the incorporation of trifluoromethyl and fluoroalkyl groups into arenes and heteroarenes are highly desirable. ${ }^{3}$ While cross-coupling approaches from aryl halides, ${ }^{4}$ boronic acids,${ }^{5}$ silanes, ${ }^{6}$ and aniline derivatives ${ }^{7}$ have facilitated the $\mathrm{CF}_{3}$ introduction, the direct aromatic $\mathrm{C}-\mathrm{H}$ trifluoromethylation represents a straight manner not requiring pre-functionalization. Recently, transition metal-catalyzed $\mathrm{C}-\mathrm{H}$ activation has emerged as an effective strategy for the construction of $\mathrm{CF}_{3}$ containing (hetero)arenes. ${ }^{8}$ Very recently, Ritter reported a site-selective late-stage trifluoromethylation of arenes via the aryl sulfonium salt intermediates. ${ }^{9}$ Moreover, there is a renaissance in aromatic $\mathrm{C}-\mathrm{H}$ trifluoromethylation by the $\mathrm{CF}_{3}$ radical addition mechanism. ${ }^{10} \mathrm{~A}$ variety of reagents have been extensively used as $\mathrm{CF}_{3}$ radical precursors, including $\mathrm{CF}_{3} \mathrm{I}^{11}$ $\mathrm{CF}_{3} \mathrm{Br}^{12} \mathrm{CF}_{3} \mathrm{SO}_{2} \mathrm{Cl}_{,}{ }^{13}\left(\mathrm{CF}_{3} \mathrm{SO}_{2}\right)_{2} \mathrm{O},{ }^{14} \mathrm{CF}_{3} \mathrm{SO}_{2} \mathrm{CH}(\mathrm{Me}) \mathrm{COPh},{ }^{15}$ Togni reagent, ${ }^{16}$ Umemoto reagent, ${ }^{17} \mathrm{TMSCF}_{3},{ }^{18}$ Langlois reagent $\mathrm{NaSO}_{2} \mathrm{CF}_{3},{ }^{19}$ and $\mathrm{Zn}\left(\mathrm{SO}_{2} \mathrm{CF}_{3}\right)_{2} \cdot{ }^{20}$ Nevertheless, the high cost, environmental impact, and multistep preparation of these reagents hamper their further application on large scales. In this regard, it is a long-term interest for chemists to develop new trifluoromethylation reactions with inexpensive and easyto-handle $\mathrm{CF}_{3}$ sources.

Trifluoroacetic acid (TFA) and trifluoroacetic anhydride (TFAA) are among the most attractive trifluoromethylation reagents with respect of their low prices, ease of handling, and availability in large quantities. The major challenge associated with this type of transformations is to produce the trifluoroace- tate radical under mild conditions, which after prompt $\mathrm{CO}_{2}$ extrusion affords the desired $\mathrm{CF}_{3}$ radical. Yoshida and subsequently Bräse disclosed that bis(trifluoroacetyl)peroxide (BTFAP) generated from TFAA and hydrogen peroxide could undergo a homolytic cleavage, followed by the release of $\mathrm{CO}_{2}$ to yield the $\mathrm{CF}_{3}$ radical. ${ }^{21}$ Remarkably, Stephenson reported that the adducts of TFAA and pyridine $N$-oxide derivatives were ready to be reduced via a single-electron transfer pathway to furnish the $\mathrm{CF}_{3}$ radical effectively. ${ }^{22}$ Very recently, Qing developed a hypervalent iodine reagent $\mathrm{C}_{6} \mathrm{~F}_{5} \mathrm{I}\left(\mathrm{OCOCF}_{3}\right)_{2}$ easily accessible from $\mathrm{C}_{6} \mathrm{~F}_{5} \mathrm{I}$ and TFA by an oxidation procedure, which could provide the $\mathrm{CF}_{3}$ radical under reductive conditions as well. ${ }^{23}$ TFA and its salts are commercially abundant and low priced. However, because of their exceedingly high oxidation potentials, the direct oxidation of TFA and its salts to the trifluoroacetate radical requires harsh conditions (Figure 1, oxidative pathway), for instance, strong oxidants, ${ }^{24}$ electrolysis with forcing potentials, ${ }^{25}$ high temperatures, ${ }^{26}$ and ultraviolet irradiation. ${ }^{27}$ In addition, a large excess of TFA or its salts was usually necessary in these reactions. For all these reasons, mild and efficient protocols for the direct conversion of TFA to $\mathrm{CF}_{3}$ radical are still in high demand.

Herein, we present a new strategy for the use of TFA as a trifluoromethylation reagent via visible light photoredox catalysis. The working hypothesis is outlined in Figure 1. We envisioned that TFA would condense with a sulfoxide to form the sulfonium intermediate, followed by a single-electron transfer event with the photo-excited $* \mathrm{Ru}(\mathrm{bpy})_{3}{ }^{2+}$ to afford $\mathrm{Ru}(\mathrm{bpy}) 3_{3}{ }^{3+},{ }^{28}$ a sulfide, and trifluoroacetate radical after fragmentation. The resultant radical should rapidly collapse to generate the $\mathrm{CF}_{3}$ radical, which would add to the arene to form the radical adduct. Finally, the radical adduct could be oxidized by $\mathrm{Ru}(\mathrm{bpy})_{3}{ }^{3+}$, and then deprotonated to furnish the trifluoromethylated arene, while regenerating the photocatalyst $\mathrm{Ru}(\mathrm{bpy})_{3}{ }^{2+}$. 

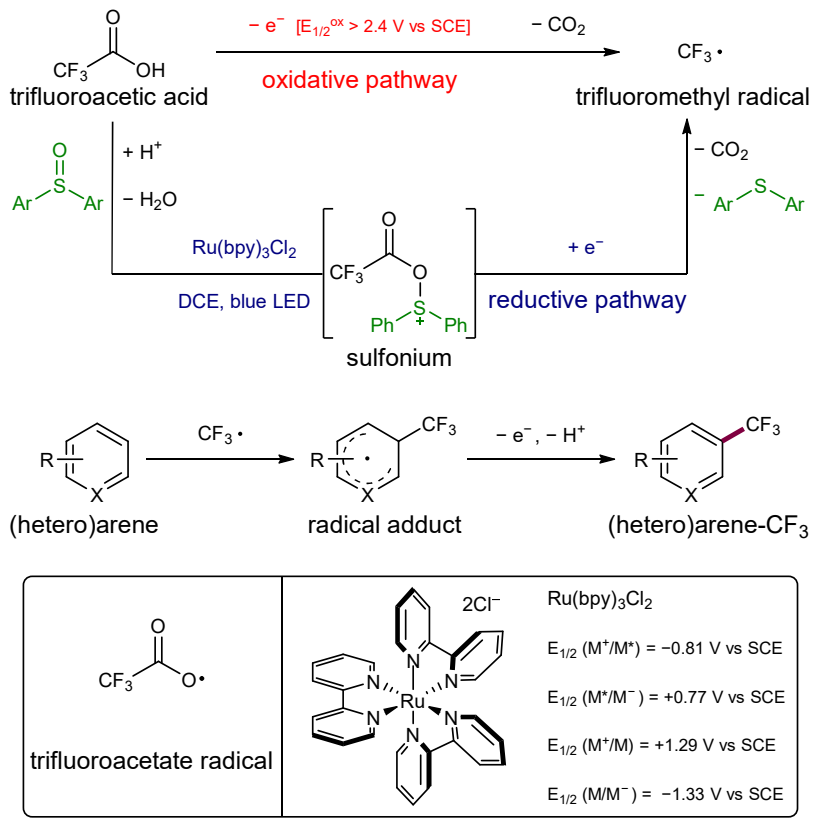

Figure 1. Working hypothesis for the trifluoromethylation.

To explore the proposed aromatic $\mathrm{C}-\mathrm{H}$ trifluoromethylation with TFA, mesitylene was chosen as the model substrate (Table 1). Our initial experimental results showed that DMSO was not a capable activator as compared to diaryl sulfoxides. After careful investigation of various reaction parameters, the trifluoromethylation products 1-mono and 1-bis were obtained in a total yield of $76 \%$ (mono:bis $=6: 1$ ) with bis(4chlorophenyl) sulfoxide as the activator (entry 1 ). This sulfoxide is commercially available and inexpensive, and could be recycled quantitatively in the forms of sulfoxide and thioether. Besides, other sulfoxides were also evaluated for this reaction. While bis(4-bromophenyl) sulfoxide exhibited a comparable efficiency, the electron-richer sulfoxides were less reactive (entries 2-4). Moreover, replacement of the solvent with $\mathrm{CH}_{2} \mathrm{Cl}_{2}$ resulted in a decreased total yield (62\%, entry 5$)$. To our delight, the switch of irradiation wavelength from $427 \mathrm{~nm}$ to $390 \mathrm{~nm}$ rendered an improved outcome $(80 \%$, entry 6$)$. When both TFA and sulfoxide were reduced to 1 equivalent each, it still afforded the products in 59\% combined yield (entry 7). Control experiments indicated that the sulfoxide, photocatalyst and light were all essential to this transformation (entries 8-10). Finally, by the addition of free radical scavengers, the aromatic $\mathrm{C}-\mathrm{H}$ trifluoromethylation was severely inhibited with BHT (entry 11) and even shut down (entry 12) in the presence of TEMPO along with the formation of $\mathrm{BHT}_{-} \mathrm{CF}_{3}$ and TEMPO- $\mathrm{CF}_{3}$ adducts, respectively, supporting a radical mechanism in these transformations.
Table 1. Optimization for the Trifluoromethylation ${ }^{a}$

$$
\begin{aligned}
& \text { } \\
& \text { Entry Variation from standard conditions 1-mono/1-bis, \% Yield } \\
& 1 \text { none 65/11 } \\
& \left.2 \text { (4-BrPh })_{2} \mathrm{SO} \text { instead of (4-CIPh) }\right)_{2} \mathrm{SO} \quad 60 / 13 \\
& \left.3 \quad \mathrm{Ph}_{2} \mathrm{SO} \text { instead of (4-CIPh) }\right)_{2} \mathrm{SO} \quad 55 / 5 \\
& 4 \quad(4-\mathrm{MePh})_{2} \mathrm{SO} \text { instead of (4-CIPh) }{ }_{2} \mathrm{SO} \quad 57 / 5 \\
& 5 \quad \mathrm{CH}_{2} \mathrm{Cl}_{2} \text { instead of DCE } \quad 57 / 5 \\
& 6 \quad 390 \mathrm{~nm} \text { instead of } 427 \mathrm{~nm} \quad 68 / 12 \\
& 7 \quad 1 \text { equiv. TFA and } 1 \text { equiv. (4-CIPh) } 2 \mathrm{SO} \quad 54 / 5 \\
& 8 \quad \text { without sulfoxide } 0 / 0 \\
& 9 \text { without photocatalyst } 0 / 0 \\
& 10 \text { without light } 0 / 0 \\
& 112 \text { equiv. BHT } 37 / 1 \\
& 12 \text { equiv. TEMPO } 0 / 0
\end{aligned}
$$

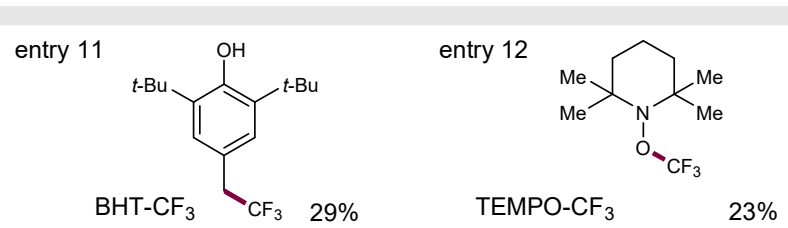

${ }^{a}$ Yields determined by ${ }^{19} \mathrm{~F}$ NMR spectroscopy using trifluoromethylbenzene as an internal standard. BHT =3,5-di-tert-butyl-4hydroxytoluene. TEMPO = 2,2,6,6-tetramethylpiperidine-1-oxyl.

With the established optimal conditions, we began to examine the substrate scope of the decarboxylative trifluoromethylation protocol by employing structurally diverse arenes and heteroarenes. As shown in Scheme 1, a variety of aromatic compounds could be transformed into the valuable trifluoromethylated products in moderate to excellent isolated yields. Electron-enrichment favors the electrophilic trifluoromethylation. Benzene derivatives bearing electron-donating alkyl or alkoxy substituents were amenable to the protocol (1-12). It is of note that the liable boronate group was tolerated under the reaction conditions, and could be utilized for further transformations (2). To our delight, the trifluoromethylation of naphthalene proceeded well with a preference at the $\alpha$ position (13). The introduction of methoxy groups also rendered quinone and pyridine good substrates for the protocol (14 and 15). A series of pyridinones and coumarins reacted selectively at the $\alpha$ positions (16-22). Moreover, five-membered heteroarenes proved suitable substrates for the radical trifluoromethylation, including pyrroles, indoles, furans, benzofurans, thiophens, and benzothiophens $(\mathbf{2 3}-\mathbf{5 1})$. For this type of heteroarenes, the 2-positions if available were preferentially trifluoromethylated. Gratifyingly, the acid-sensitive Boc protecting group survived from the reaction (24 and $\mathbf{3 2}$ ). Notably, the compatibility with boronate and bromide groups illustrated an orthogonal reactivity to the transition metal-catalyzed $\mathrm{C}-\mathrm{X}$ trifluoromethylation $(2,17,31$ and 46). Then, the more complex, biologically active heteroarenes, caffeine and pentoxifylline, were also functionalized (52 and 53), as well as the electron-deficient oxazole substrate (54). 
Scheme 1. Scope of the arenes and heteroarenes for trifluoromethylation ${ }^{a}$

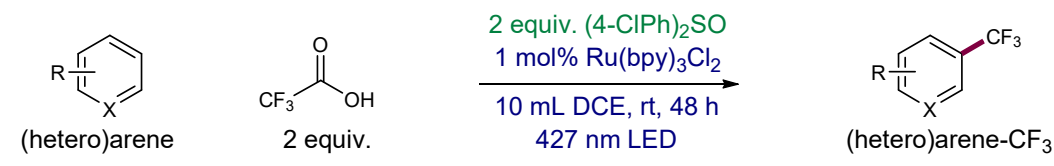

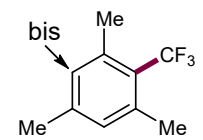

$1,80 \%(6.7: 1)$<smiles>COc1ccc(OC)c(C(F)(F)F)c1</smiles>

$7,56 \%$<smiles>FC(F)(F)c1cccc2ccccc12</smiles>

$13,76 \%(4.4: 1)$<smiles></smiles>

$19,46 \%$<smiles>CC(=O)c1ccc(C(F)(F)F)n1-c1ccccc1</smiles>

$25,82 \%(3.5: 1)$<smiles>COC(=O)c1cc(Br)c(C(F)(F)F)n1C</smiles>

$31,85 \%$<smiles>CCOC(=O)c1[nH]c2ccccc2c1C(F)(F)F</smiles>

$37,45 \%$<smiles>Cc1c(C(F)(F)F)oc2ccccc12</smiles>

43, $44 \%$<smiles>COc1csc(C(F)(F)F)c1OC</smiles>

49, $64 \%$<smiles>Cc1cc(C)c(C(F)(F)F)c([N+](=O)[O-])c1[PH2+]</smiles>

2, $67 \%$<smiles>Cc1ccc(C(C)(C)C)cc1C(F)(F)F</smiles>

8, $46 \%$<smiles>COC1=CC(=O)C(C(F)(F)F)=C(OC)C1=O</smiles>

14, $82 \%$<smiles>CCOc1ccc2c(C)c(C(F)(F)F)c(=O)oc2c1</smiles>

20, $68 \%$

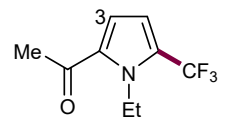

26, $80 \%(4: 1)$<smiles></smiles>

$32,52 \%$<smiles>CC(=O)c1ccc(C(F)(F)F)o1</smiles>

$38,62 \%$<smiles>COc1c(C(F)(F)F)ccc2cc(C(C)=O)oc12</smiles>

$44,31 \%$

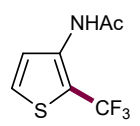

50, $65 \%$<smiles>COc1cc(OC)c(C(F)(F)F)c(OC)c1</smiles>

3, $73 \%$<smiles>COc1ccc(C(C)(C)C)cc1C(F)(F)F</smiles>

9, $59 \%$<smiles>COc1ccc(C(F)(F)F)c(OC)n1</smiles>

$15,52 \%$<smiles>Cc1c(C(F)(F)F)c(=O)oc2cc3c(cc12)OCO3</smiles>

21, $46 \%$<smiles>CC(=O)c1ccc(C(F)(F)F)n1C</smiles>

27, $81 \%$<smiles>CC(=O)c1c(C(F)(F)F)n(C(C)=O)c2ccccc12</smiles>

33, $48 \%$<smiles>COC(=O)c1ccc(C(F)(F)F)o1</smiles>

$39,59 \%$

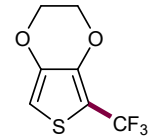

45, $44 \%$<smiles>COC(=O)c1sc2ccccc2c1C(F)(F)F</smiles>

51, $52 \%$<smiles>COc1ccc(O)cc1O</smiles>

4, $47 \%$<smiles>COc1cc([N+](=O)[O-])c(OC)c(OC)c1C(F)(F)F</smiles>

$10,45 \%$<smiles>COC(=O)c1cc(C(F)(F)F)c(=O)n(-c2ccccc2)c1</smiles>

16, $54 \%$<smiles>COc1cc(OC)c2cc(C(F)(F)F)c(=O)oc2c1</smiles>

22, $66 \%$<smiles>CC(=O)c1ccc(C(F)(F)F)[nH]1</smiles>

28, $77 \%$<smiles>COC(=O)c1c(C(F)(F)F)n(C)c2ccccc12</smiles>

34, $45 \%$<smiles>O=C(OOc1ccccc1)c1ccc(C(F)(F)F)o1</smiles>

40, $58 \%$<smiles>FC(F)(F)c1scc(Br)c1Br</smiles>

46, $56 \%$<smiles>COc1cc(C(F)(F)F)c(OC)cc1C</smiles>

5, $52 \%$<smiles>COc1cc(C(C)=O)c(C(F)(F)F)c(OC)c1OC</smiles>

11, $50 \%$<smiles>Cn1ccc(Br)c(C(F)(F)F)c1=O</smiles>

17, $60 \%$<smiles>[3H]n1cccc1C(F)(F)F</smiles>

23, $68 \%$<smiles>O=C(c1ccccc1)c1ccc(C(F)(F)F)[nH]1</smiles>

29, $63 \%$<smiles>COC(=O)c1c(C(F)(F)F)[nH]c2ccccc12</smiles>

$35,37 \%$<smiles>O=C(c1ccco1)c1ccc(C(F)(F)F)o1</smiles>

$41,43 \%$<smiles>CC(=O)c1cc(C)c(C(F)(F)F)s1</smiles>

47, $60 \%$<smiles>Cn1c(=O)c2c(nc(C(F)(F)F)n2C)n(C)c1=O</smiles>

52, 35\%<smiles>CC(=O)[Al]n1c(=O)c2c(nc(C(F)(F)F)n2C)n(C)c1=O</smiles>

53, $30 \%$<smiles>COc1cc(OC)c(C(F)(F)F)cc1OC</smiles>

6, $47 \%$<smiles>COC(=O)c1cc(OC)c(OC)c(OC)c1C(F)(F)F</smiles>

$12,45 \%$<smiles>Cc1c(C(F)(F)F)c(=O)n(-c2ccccc2)c2ccccc12</smiles>

$18,44 \%$<smiles>CC(C)(C)OC(=O)n1c(C(=O)O)ccc1C(F)(F)F</smiles>

24, $92 \%(2.4: 1)$<smiles>COC(=O)c1ccc(C(F)(F)F)n1S(C)(=O)=O</smiles>

30, $65 \%(5.5: 1)$<smiles>CC(=O)c1[nH]c2ccccc2c1C(F)(F)F</smiles>

$36,50 \%$

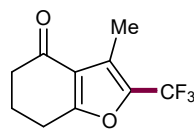

42, $59 \%$<smiles>CCOC(=O)c1ccc(C(F)(F)F)s1</smiles>

48, $58 \%(1.8: 1)$<smiles>Cc1nc(C)c(C(F)(F)F)o1</smiles>

$54,67 \%$

${ }^{a}$ Isolated yields. ${ }^{b} 390 \mathrm{~nm}$ LED used. ${ }^{c}$ Yields determined by ${ }^{19} \mathrm{~F}$ NMR spectroscopy using trifluoromethylbenzene as an internal standard. 
While a great deal of efforts has been devoted to the $\mathrm{CF}_{3}$ introduction, synthetic procedures for incorporating other fluoroalkyl (Rf) groups are relatively limited. To this end, we decided to investigate the scope of fluoroalkyl carboxylic acids, which resulted in the extension of the current protocol to efficient $\mathrm{C}-\mathrm{H}$ perfuoroalkyaltion and chlorodifluoromethylation $^{29}$ (Scheme 2). We were pleased to find with the corresponding perfluoroalkyl carboxylic acids, the $\mathrm{C}_{2} \mathrm{~F}_{5}, \mathrm{C}_{3} \mathrm{~F}_{7}, \mathrm{C}_{4} \mathrm{~F}_{9}$ and $\mathrm{C}_{5} \mathrm{H}_{11}$ groups were successfully installed onto the arene ring without loss of reactivity as the chain goes longer $(\mathbf{5 5}-\mathbf{5 8})$ Until the case of $\mathrm{C}_{6} \mathrm{~F}_{13}$, a diminished yield was observed perhaps because of the poor solubility of $\mathrm{C}_{6} \mathrm{~F}_{13} \mathrm{CO}_{2} \mathrm{H}$ (59). Furthermore, the chlorodifluoromethylation proceeded smoothly with a broad range of arenes and heteroarenes (60-67).

Scheme 2. Scope of the fluoroalkyl carboxylic acids

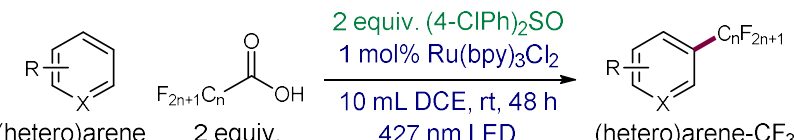

(hetero)arene 2 equiv. $\quad 427 \mathrm{~nm} \mathrm{LED}$ (hetero)arene-CF<smiles>COC1=CC(=O)C(C(F)(F)F)=C(OC)C1=O</smiles>

$55,83 \%$<smiles>CC1=CC(=O)C(C)C(=NO)C1=O</smiles>

$56,80 \%$

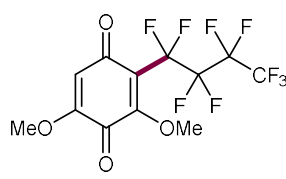

$57,89 \%$<smiles>COC1=CC(=O)C(C(F)(F)C(F)(F)C(F)(F)C(F)(F)C(F)(F)F)=C(OC)C1=O</smiles>

$58,80 \%$<smiles>COC1=CC(=O)C(C(F)(F)C(F)(F)C(F)(F)C(F)(F)C(F)(F)C(F)(F)F)=C(OC)C1=O</smiles>

$59,63 \%$
$60,74 \%$<smiles>Cc1cc(C)c(C(F)(F)Cl)c(C)c1</smiles><smiles>Cn1ccc(Br)c(C(F)(F)Cl)c1=O</smiles>

$61,52 \%$<smiles>Cc1c(C(F)(F)Cl)oc2c1C(=O)CCC2</smiles>

$64,72 \%$

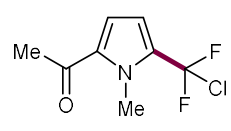

$62,80 \%$<smiles>CC(=O)c1ccc(C(F)(F)Cl)[nH]1</smiles>

$63,66 \%$

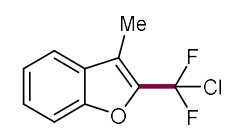

$65.67 \%$<smiles>C=C(C)Cn1c(=O)c2c(nc(C(F)(F)Cl)n2C)n(C)c1=O</smiles>

$66,44 \%$<smiles>Cc1nc([N+](=O)[O-])c(C(F)(F)Cl)o1</smiles>

$67,63 \%$
${ }^{a}$ Isolated yields. ${ }^{b} 390 \mathrm{~nm}$ LED used. ${ }^{c}$ Yields determined by ${ }^{19} \mathrm{~F}$ NMR spectroscopy using trifluoromethylbenzene as an internal standard.

In summary, we have developed a mild and practical method that allows for the decarboxylative radical trifluoromethylation, perfuoroalkylation and chlorodifluoromethylation of (hetero)arenes using inexpensive and abundant trifluoracetic acid and the related carboxylic acids. A diverse array of arenes and heteroarenes were successfully transformed into valued fluoroalkylated compounds. The combination of photoredox catalysis and a diarylsulfoxide provides a platform for the facile generation of fluoroalkyl radicals from the corresponding fluoroalkyl carboxylic acids under mild conditions. Further development of our described protocol in terms of easy removal the sulfide byproduct as well as possible use of the sulfoxide activator in a catalytic amount is under active investigation in our lab.

\section{ASSOCIATED CONTENT}

\section{Supporting Information}

The Supporting Information is available free of charge at http://pubs.acs.org.

Experimental procedures; spectral data (PDF)

\section{AUTHOR INFORMATION}

\section{Corresponding Author}

*jjin@sioc.ac.cn.

\section{Author Contributions}

$\$$ These authors contributed equally.

\section{Notes}

The authors declare no competing financial interest.

\section{ACKNOWLEDGMENT}

The authors thank for financial support from Natural Science Foundation of Shanghai (19ZR1468700), Shanghai Institute of Organic Chemistry, and Chinese Academy of Sciences.

\section{REFERENCES}

(1) (a) Müller, K.; Faeh, C.; Diederich, F. Fluorine in Pharmaceuticals: Looking Beyond Intuition. Science 2007, 317, 1881-1886. (b) Purser, S.; Moore, P. R.; Swallow, S.; Gouverneur, V. Fluorine in Medicinal Chemistry. Chem. Soc. Rev. 2008, 37, 320-330. (c) Wang, J.; Sánchez-Roselló, M.; Aceña, J. L.; del Pozo, C.; Sorochinsky, A. E.; Fustero, S.; Soloshonok, V. A.; Liu, H. Fluorine in Pharmaceutical Industry: Fluorine-Containing Drugs Introduced to the Market in the Last Decade (2001-2011). Chem. Rev. 2014, 114, 2432-2506. (d) Zhou, Y.; Wang, J.; Gu, Z.; Wang, S.; Zhu, W.; Aceña, J. L.; Soloshonok, V. A.; Izawa, K.; Liu, H. Next Generation of FluorineContaining Pharmaceuticals, Compounds Currently in Phase II-III Clinical Trails of Major Pharmaceutical Companies: New Structral Trends and Therapeutic Areas. Chem. Rev. 2016, 116, 422-518.

(2) (a) Furuya, T.; Kamlet, A. S.; Ritter, T. Catalysis for Fluorination and Trifluoromethylation. Nature 2011, 473, 470-477. (b) Liang, T.; Neumann, C. N.; Ritter, T. Introduction of Fluorine and FluorineContaining Functional Groups. Angew. Chem. Int. Ed. 2013, 52, 8214-8264. (c) Campbell, M. G.; Ritter, T. Late-Stage Fluorination: From Fundamentals to Application. Org. Process. Res. Dev. 2014, 18 , 474-480. (d) Modern Carbon-Fluorine Bond Forming Reactions for Aryl Fluoride Synthesis. Chem. Rev. 2015, 115, 612-633. (e) Neumann, C. N.; Ritter, T. Facile C-F Bond Formation through a Concerted Nucleophilic Aromatic Substitution Mediated by the PhenoFluor Reagent. Acc. Chem. Res. 2017, 50, 2822-2833.

(3) (a) Tomashenko, O. A.; Grushin, V. V. Aromatic Trifluoromethylation with Metal Complexes. Chem. Rev. 2011, 111, 4475-4521. (b) Alonso, C.; Martínez de Marigota, E.; Rubiales, G.; Palacios, F. Carbon Trifluoromethylation Reactions of Hydrocarbon Derivatives and Heteroarenes. Chem. Rev. 2015, 115, 1847-1935.

(4) (a) Grushin, V. V.; Marshall, W. J. Facile $\mathrm{Ar}-\mathrm{CF}_{3}$ Bond Formation at Pd. Strikingly Different Outcomes of Reductive Elimination from $\left[\left(\mathrm{Ph}_{3} \mathrm{P}\right)_{2} \mathrm{Pd}\left(\mathrm{CF}_{3}\right) \mathrm{Ph}\right]$ and $\left[(\mathrm{X}\right.$ antphos $\left.) \mathrm{Pd}\left(\mathrm{CF}_{3}\right) \mathrm{Ph}\right]$. J. Am. Chem. Soc. 2006, 128, 12644-12645. (b) Dubinina, G. G.; Furutachi, H.; Vicic, D. A. Active Trifluoromethylating Agents from Well-Defined Copper(I)-CF 3 Complexes. J. Am. Chem. Soc. 2008, 130, 8600-8601. 
(c) Cho, E. J.; Senecal, T. D.; Kinzel, T.; Zhang, Y.; Watson, D. A.; Buchwald, S. L. The Palladium-Catalyzed Trifluoromethylation of Aryl Chlorides. Science 2010, 328, 1679-1681. (d) Ball, N. D.; Kampf, J. W.; Sanford, M. S. Aryl- $\mathrm{CF}_{3}$ Bond Forming Reductive Elimination from Palladium(IV). J. Am. Chem. Soc. 2010, 132, 2878-2879. (e) Zhang, C.-P.; Wang, Z.-L.; Chen, Q.-Y.; Zhang, C.-T.; Gu, Y.-C.; Xiao, J.-C. Copper-Mediated Trifluoromethylation of Heteroaromatic Compounds by Trifluoromethyl Sulfonium Salts. Angew. Chem. Int. Ed. 2011, 50, 1896-1900. (f) Ball, N. D.; Gary, J. B.; Ye, Y.; Sanford, M. S. Mechanistic and Computational Studies of Oxidatively-Induced Aryl- $\mathrm{CF}_{3}$ Bond Formation at Pd: Rational Design of Room Temperature Aryl Trifluoromethylation. J. Am. Chem. Soc. 2011, 133, 75777584. (g) Morimoto, H.; Tsubogo, T.; Litvinas, N. D.; Hartwig, J. F. A Broadly Applicable Copper Reagent for Trifluoromethylations and Perfluoroalkylations of Aryl Iodides and Bromides. Angew. Chem. Int. Ed. 2011, 50, 3793-3798. (h) Huiban, M.; Tredwell, M.; Mizuta, S.; Wan, Z.; Zhang, X.; Collier, T. L.; Gouverneur, V.; Passchier, J. A broadly applicable $\left[{ }^{18} \mathrm{~F}\right]$ trifluromethylation of Aryl and Heteroaryl Iodides for PET Imaging. Nature Chem. 2013, 5, 941-944. (i) Chen, M.; Buchwald, S. L. Rapid and Efficient Trifluoromethylation of Aromatic and Heteroaromatic Compounds Using Potassium Trifluoroacetate Enabled by a Flow System. Angew. Chem. Int. Ed. 2013, 52, 11628-11631. (j) Le, C.; Chen, T. Q.; Liang, T.; Zhang, P.; MacMillan, D. W. C. A Radical Approach to the Copper Oxidative Addition Problem: Trifluoromethylation of Bromoarenes. Science 2018, 360, 1010-1014

(5) (a) Chu, L.; Qing, F.-L. Copper-Mediated Oxidative Trifluoromethylation of Boronic Acids. Org. Lett. 2010, 12, 5060-5063. (b) Senecal, T. D.; Parsons, A. T.; Buchwald, S. L. Room Temperature Aryl Trifluoromethylation via Copper-Mediated Oxidative CrossCoupling. J. Org. Chem. 2011, 76, 1174-1176. (c) Xu, J.; Luo, D.-F.; Xiao, B.; Liu, Z.-J.; Gong, T.-J.; Fu, Y.; Liu, L. Copper-Catalyzed Trifluoromethylation of Aryl Boronic Acids Using $\mathrm{A} \mathrm{CF}_{3}{ }^{+}$Reagent. Chem. Commun. 2011, 47, 4300-4302. (d) Liu, T.; Shen, Q. CopperCatalyzed Trifluoromethylation of Aryl and Vinyl Boronic Acids with An Electrophilic Trifluoromethylating Reagent. Org. Lett. 2011, 13, 2342-2345. (e) Ye, Y.; Sanford, M. S. Merging Visible-Light Photocatalysis and Transition-Metal Catalysis in the Copper-Catalyzed Trifluoromethylation of Boronic Acids with $\mathrm{CF}_{3} \mathrm{I}$. J. Am. Chem. Soc. 2012, 134, 9034-9037. (f) Ye, Y.; Künzi, S. A.; Sanford, M. S. Practical Method for the $\mathrm{Cu}$-Mediated Trifluoromethylation of Arylboronic Acids with $\mathrm{CF}_{3}$ Radicals Derived from $\mathrm{NaSO}_{2} \mathrm{CF}_{3}$ and tert-Butyl Hydroperoxide (TBHP). Org. Lett. 2012, 14, 4979-4981. (g) Li, Y.; Wu, L.; Neumann, H.; Beller, M.; Copper-Catalyzed Trifluoromethylation of Aryl- and Vinylboronic Acids with Generation of $\mathrm{CF}_{3}$ Radicals. Chem. Commun. 2013, 49, 2628-2630. (h) Li, X.; Zhao, J.; Zhang, L.; Hu, M.; Wang, L.; Hu, J. Copper-Mediated Trifluoromethylation Using Phenyl Trifluoromethyl Sulfoxide. Org. Lett. 2015, 17, 298-301.

(6) Morstein, J.; Hou, H.; Cheng, C.; Hartwig, J. F. Trifluoromethylation of Arylsilanes with [(phen) $\left.\mathrm{CuCF}_{3}\right]$. Angew. Chem. Int. Ed. 2016, $55,8054-8057$

(7) (a) Dai, J.-J.; Fang, C.; Xiao, B.; Yi, J.; Liu, Z.-J.; Liu, L.; Fu, Y. Copper-Promoted Sandmeyer Trifluoromethylation Reaction. J. Am. Chem. Soc. 2013, 135, 8436-8439. (b) Wang, X.; Xu, Y.; Mo, F.; Ji, G.; Qiu, D.; Feng, J.; Ye, Y.; Zhang, S.; Zhang, Y.; Wang, J. SilverMediated Trifluoromethylation of Aryldiazonium Salts: Conversion of Amino Group into Trifluoromethyl Group. J. Am. Chem. Soc. 2013, 135, 10330-10333. (c) Danoun, G.; Bayarmagnai, B.; Grünberg, M. F.; Gooßen, L. J. Sandmeyer Trifluoromethylation of Arenediazonium Tetrafluoroborates. Angew. Chem. Int. Ed. 2013, 52, 7972-7975. (d) Lishchynskyi, A.; Berthon, G.; Grushin, V. V. Trifluoromethylation of Arenediazonium Salts with Fluoroform-Derived $\mathrm{CuCF}_{3}$ in Aqueous Media. Chem. Commun. 2014, 50, 10237-10240.

(8) (a) Wang, X.; Truesdale, L.; Yu, J.-Q. Pd(II)-Catalyzed orthoTrifluoromethylation of Arenes Using TFA as a Promoter. J. Am. Chem. Soc. 2010, 132, 3648-3649. (b) Mu, X.; Chen, S.; Zhen, X.; Liu, G. Palladium-Catalyzed Oxidative Trifluoromethylation of Indoles at Room Temperature. Chem. Eur. J. 2011, 17, 6039-6042. (c) Hafner, A.; Bräse. Ortho-Trifluoromethylation of Functionalized Aromatic Triazenes. Angew. Chem. Int. Ed. 2012, 51, 3713-3715. (d)
Chu, L.; Qing, F.-L. Copper-Catalyzed Direct C-H Oxidative Trifluoromethylation of Heteroarenes. J. Am. Chem. Soc. 2012, 134, 12981304. (e) Zhang, X.-G.; Dai, H.-X.; Wasa, M.; Yu, J.-Q. Pd(II)Catalyzed Ortho Trifluoromethylation of Arenes and Insights into the Coordination Mode of Acidic Amide Directing Groups. J. Am. Chem. Soc. 2012, 134, 11948-11951. (f) Shang, M.; Sun, S.-Z.; Wang, H.-L.; Laforteza, B. N.; Dai, H.-X.; Yu, J.-Q. Exceedingly Fast Copper(II)Promoted ortho $\mathrm{C}-\mathrm{H}$ Trifluoromethylation of Arenes Using $\mathrm{TMSCF}_{3}$. Angew. Chem. Int. Ed. 2014, 53, 10439-10442.

(9) Ye, F.; Berger, F.; Jia, H.; Ford, J.; Wortman, A.; Börgel, J.; Genicot, C.; Ritter, T. Aryl Sulfonium Salts for Site-Selective LateStage Trifluoromethylation. Angew. Chem. Int. Ed. 2019, 58, 1461514619

(10) Studer, A. A "Renaissance" in Radical Trifluoromethylation. Angew. Chem. Int. Ed. 2012, 51, 8950-8958.

(11) Sladojevich, F.; McNeil, E.; Börgel, J.; Zheng, S.-L.; Ritter, T. Condensed-Phase, Halogen-Bonded $\mathrm{CF}_{3} \mathrm{I}$ and $\mathrm{C}_{2} \mathrm{~F}_{5} \mathrm{I}$ Adducts for Perfluoroalkylation Reactions. Angew. Chem. Int. Ed. 2015, 54, 37123716.

(12) Natte, K.; Jagadeesh, R. V.; He, L.; Rabeah, J.; Chen, J.; Taeschler, C.; Ellinger, S.; Zaragoza, F.; Neumann, H.; Brückner, A.; Beller, M. Palladium-Catalyzed Trifluoromethylation of (Hetero)Arenes with $\mathrm{CF}_{3} \mathrm{Br}$. Angew. Chem. Int. Ed. 2016, 55, 2782-2786.

(13) Nagib, D. A.; MacMillan, D. W. C. Trifluoromethylation of Arenes and Heteroarenes by Means of Photoredox Catalysis. Nature 2011, 480, 224-228.

(14) Ouyang, Y.; Xu, X.-H.; Qing, F.-L. Trifluoromethanesulfonic Anhydride as a Low-Cost and Versatile Trifluoromethylation Reagent. Angew. Chem. Int. Ed. 2018, 57, 6926-6929.

(15) Liu, P.; Liu, W.; Li, C.-J. Catalyst-Free and Redox-Neutral Innate Trifluoromethylation and Alkylation of Aromatics Enabled by Light. J. Am. Chem. Soc. 2017, 139, 14315-14321.

(16) (a) Mejía, E.; Togni, A. Rhenium-Catalyzed Trifluoromethylation of Arenes and Heteroarenes by Hypervalent Iodine Reagents. ACS Catal. 2012, 2, 521-527. (b) Charpentier, J.; Früh, N.; Togni, A. Electrophilic Trifluoromethylation by Use of Hypervalent Iodine Reagents. Chem. Rev. 2015, 115, 650-682.

(17) (a) Cheng, Y.; Yuan, X.; Ma, J.; Yu, S. Direct Aromatic C-H Trifluoromethylation via an Electro-Donor-Acceptor Complex. Chem. Eur. J. 2015, 21, 8355-8359. (b) Meucci, E. A.; Nguyen, S. N.; Camasso, N. M.; Chong, E.; Ariafard, A.; Canty, A. J.; Sanford, M. S. Nickel(IV)-Catalyzed C-H Trifluoromethylation of (Hetero)arenes. $J$. Am. Chem. Soc. 2019, 141, 12872-12879.

(18) Ye, Y.; Lee, S. H.; Sanford, M. S. Silver-Mediated Trifluoromethylation of Arenes Using $\mathrm{TMSCF}_{3}$. Org. Lett. 2011, 13, 54645467.

(19) (a) Ji, Y.; Brueckl, T.; Baxter, R. D.; Fujiwara, Y.; Seiple, I. B.; Su, S.; Blackmond, D. G.; Baran, P. S. Innate C-H Trifluoromethylation of Heterocycles. Proc. Natl. Acad. Sci. USA 2011, 108, 1441114415. (b) Li, L.; Mu, X.; Liu, W.; Wang, Y.; Mi, Z.; Li, C.-J. Simple and Clean Photoinduced Aromatic Trifluoromethylation Reaction. $J$. Am. Chem. Soc. 2016, 138, 5809-5812. (c) Ghosh, I.; Khamrai, J.; Savateev, A.; Shlapakov, N.; Antonietti, M.; König, B. Organic Semiconductor Photocatalyst Can Bifunctionalize Arenes and Heteroarenes. Science 2019, 365, 360-366.

(20) (a) Fujiwara, Y.; Dixon, J. A.; O'Hara, F.; Funder, E. D.; Dixon, D. D.; Rodriguez, R. A.; Baxter, R. D.; Herlé, B.; Sach, N.; Collins, M. R.; Ishihara, Y.; Baran, P. S. Practical and Innate CarbonHydrogen Functionalization of Heterocycles. Nature 2012, 492, 95-99. (b) O'Brien, A. G.; Maruyama, A.; Inokuma, Y.; Fujita, M.; Baran, P. S.; Blackmond, D. G. Radical C-H Functionalization of Heteroarenes under Electrochemical Control. Angew. Chem. Int. Ed. 2014, 53, 11868-11871.

(21) (a) Sawada, H.; Nakayama, M.; Yoshida, M.; Yoshida, T.; Kamigata, N. Trifluoromethylation of Aromatic Compounds with Bis(trifluoroacetyl) Peroxide. J. Fluorine Chem. 1990, 46, 423-431. (b) Zhong, S.; Hafner, A.; Hussal, C.; Nieger, M.; Bräse, S. RSC Adv. 2015, 5, 6255-6258.

(22) (a) Beatty, J. W.; Douglas J. J.; Cole, K. P.; Stephenson, C. R. J. A Scalable and Operationally Simple Radical Trifluoromethylation. Nat. Commun. 2015, 6, 7919. (b) Beatty, J. W.; Douglas, J. J.; Miller, 
R.; McAtee, R. C.; Cole, K. P.; Stephenson C. R. J. Photochemical Perfluoroalkylation with Pyridine $N$-Oxides: Mechanistic Insights and Performance on a Kilogram Scale. Chem 2016, 1, 456-472.

(23) Yang, B.; Yu, D.; Xu, X.-H.; Qing, F.-L. Visible-Light Photoredox Decarboxylation of Perfluoroarene Iodine(III) Trifluoroacetates for $\mathrm{C}-\mathrm{H}$ Trifluoromethylation of (Hetero)arenes. ACS Catal. 2018, 8 , 2839-2843.

(24) Tanabe, Y.; Matsuo, N.; Ohno, N. Direct Perfluoalkylation Including Trifluoromethylation of Aromatics with Perfluoro Carboxylic Acids Mediated by Xenon Difluoride. J. Org. Chem. 1988, 53, 45824585.

(25) Depecker, C.; Marzouk, H.; Trevin, S.; Devynck, J. Trifluoromethylation of Aromatic Compounds via Kolbe Electrolysis in Pure Organic Solvent. Study on Laboratory and Pilot Scale. New J. Chem. 1999, 23, 739-742.

(26) Shi, G.; Shao, C.; Pan, S.; Yu, J.; Zhang, Y. Silver-Catalyzed C$\mathrm{H}$ Trifluoromethylation of Arenes Using Trifluoroacetic Acid as the Trifluoromethylating Reagent. Org. Lett. 2015, 17, 38-41.

(27) (a) Lai, C.; Mallouk, T. E. A New Approach to the Photochemical Trifluoromethylation of Aromatic Compounds. J. Chem. Soc., Chem. Commun. 1993, 1359-1361. (b) Lin, J.; Kan, J.; Huang, S.; Su, W.; Li, Y. Photo-Driven Redox-neutral Decarboxylative CarbonHydrogen Trifluoromethylation of (hetero)arenes with Trifluoroacetic Acid. Nat. Commun. 2017, 8, 14353.

(28) Prier, C. K.; Rankic, D. A.; MacMillan, D. W. C. Visible Light Photoredox Catalysis with Transition Metal Complexes: Applications in Organic Synthesis. Chem. Rev. 2013, 113, 5322-5363.

(29) McAtee, R. C.; Beatty, J. W.; McAtee, C. C.; Stephenson, C. R. J. Radical Chlorodifluoromethylation: Providing a Motif for (Hetero)arene Diversification. Org. Lett. 2018, 20, 3491-3495. 


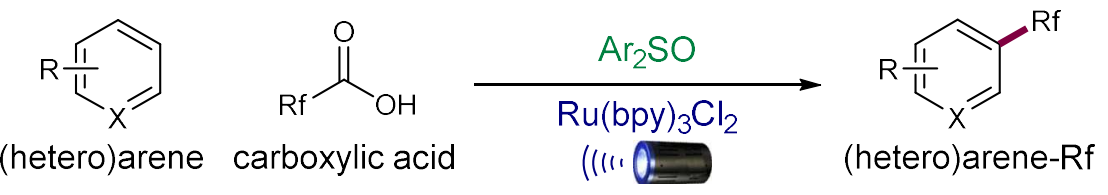

$\mathrm{Rf}=\mathrm{CF}_{3}, \mathrm{C}_{2} \mathrm{~F}_{5}, \mathrm{C}_{3} \mathrm{~F}_{7}, \mathrm{C}_{4} \mathrm{~F}_{9}, \mathrm{C}_{5} \mathrm{~F}_{11}, \mathrm{C}_{6} \mathrm{~F}_{13}, \mathrm{CF}_{2} \mathrm{Cl}$ 